\title{
PENGARUH BEBERAPA JENIS PESTISIDA NABATI TERHADAP HAMA ULAT GRAYAK (Spodoptera litura F.) PADA TANAMAN SAWI (Brassica Juncea L ) DI LAPANGAN
}

\author{
MAKSIMILIANUS BATE \\ BPTP Kabupaten Nagekeo Jln Trans Ende-Nagekeo Kabupaten Nagekeo, \\ Propinsi Nusa Tenggara Timur \\ maksibate@yahoo.co.id
}

\begin{abstract}
The effect of some vegetable pesticides on grayak pests (Spodoptera litura f.) on mustard (brassica juncea L.) plants in the field. This study aims to determine the effect of extracts of tobacco plants, cloves, lemongrass, neem seeds, and chillis on the development of gray pests caterpillars Spodoptera litura F. and determine sure plant extracts against armyworms. The design used was a randomized group design (RCBD) with the treatment of 5 types of vegetable pesticides, namely E1 (tobacco extract) E2 (clove extract) E3 (citronella extract) E4 (neem extract) E5 (red chili extract). The observational variables in this study were insects intensity, pest mortality, plant fresh weight, and original weight per hectare. The results showed that five types of vegetable pesticide extract affected the armyworm Spodoptera litura F. Tobacco leaf extract was an appropriate and effective plant against the mortality of armyworm by $32 \%$. The lowest insect intensity in the treatment of tobacco extract by $25 \%$, fresh weight of planting mustard was equal to $112,85 \mathrm{gr}$, and the original weight of plants per hectare amounted to 28.21 tons.
\end{abstract}

Keywords : Botanical Pesticides, Effectiveness, Spodoptera litura F

\section{PENDAHULUAN}

Salah satu faktor yang dapat menurunkan produksi tanaman budidaya antara lain adalah organisme pengganggu tanaman (OPT), disamping dapat menyebabkan rendahnya kualitas tanaman yang dibudidayakan, OPT juga mengakibatkan produksi per satuan luas menjadi rendah. Organisme Pengganggu tanaman (OPT) yang sering menimbulkan kerusakan tanaman hortikultura baik buah-buahan maupun sayuran adalah ulat grayak (Spodoptera litura F.), yang merupakan salah satu hama penting yang menyerang tanaman palawija dan sayuran. Hama ini sering mengakibatkan penurunan produktivitas bahkan kegagalan panen karena menyebabkan daun dan buah sayuran menjadi sobek, terpotong-potong dan berlubang (Samsudin 2008).

Menurut data Statistik Nasional, total produksi sawi Nasional tahun 2013 mencapai 635.728 ton, sedangkan pada tahun 2014 mengalami penurunan total 
produksi sebesar 597.675 ton (BPS Nasional, 2014). Produksi sawi Propinsi NTT pada tahun 2013 mencapai 5.042 ton, sementara pada tahun 2014 produksi sawi mencapai 6.120 ton (BPS NTT, 2014). Berdasarkan data Dinas Pertanian Kabupaten Ende tahun 2013 produktivitas sawi pada tahun 2013 sebesar 945,5 kw/ha, sedangkan pada tahun 2014 produktivitas sawi hanya mencapai $495 \mathrm{kw} / \mathrm{ha}$ sehingga mengalami penurunan produktivitas sebesar 450.5 kw/ha (BPS Kabupaten Ende, 2014). Salah satu faktor yang menyebabakan penurunan produktivitas tanaman sawi adalah serangan hama.

Hama yang menyerang tanaman sawi salah satunya adalah ulat grayak (Spodoptera litura F.). Hama ini umumnya menyerang berbagai macam tanaman sayuran. Ulat grayak (Spodoptera litura F.) bersifat polifagus, larva ini mempunyai inang lebih kurang 90-200 spesies tumbuhan dari 18 famili. Di Indonesia spodoptera litura F. merupakan salah satu hama penting yang banyak menyerang tanaman palawija dan sayuran dengan tingkat kerusakan yang tinggi. Hama ini tersebar luas di daerah dengan iklim panas dan lembab dari subtropis sampai daerah tropis. Gejala serangan hama ulat grayak mirip gejala serangan hama belalang, dimana daun-daun di gerek ulat dari arah tepi daun menuju tulang daun. Serangan berat pada daun kubis tinggal tulangtulang daunnya saja (Pramono, 2005), bahkan kehilangan hasil yang di sebabkan oleh serangan hama ini dapat mencapai $40-60 \%$ dengan intensitas serangan yang berat (Harahap, 2009).
Gejala serangan yang diakibatkan oleh stadia larva ulat grayak yang masih kecil merusak daun dengan meninggalkan sisa-sisa epidermis pada bagian atas dan tinggal tulang-tulang daun saja. Larva yang besar memakan tulang daun dan buahnya. Gejala serangannya tidak beraturan, bahkan hama ini juga memakan tunas dan bunga. Pada serangan berat menyebabkan daun menjadi gundul. Ulat grayak (Spodoptera litura F.) hama penting yang dapat merusak hampir semua tanaman pertanian seperti kedelai, tembakau, jagung, cabai, kacang hijau, sawi dan lain-lain (Sudarmo, 1992).

Hasil penelitianWarsi Rahmat Atmadja (2010) pada pengujian di laboratorium dengan pengaruh ekstrak cengkeh dan serai wangi pada hama ulat grayak dengan konsentrasi $10 \mathrm{ml}$ menyebabkan mortalitas hama ulat grayak sebesar $100 \%$. Hasil penelitian Maya Rumpumbo (2010) menunjukkan bahwa pemberian ekstrak biji mimba dengan konsentrasi $30 \mathrm{ml} / \mathrm{L}$ air efektif dalam mengendalikan populasi ulat Plutella xylostella pada tanaman kubis.

Selanjutnya Oleszek (2000) juga melaporkan bahwa senyawa saponin memiliki sifat antimikroba karena kemampuannya berinteraksi dengan sterol pada membran sehingga menyebabkan kebocoran protein dan enzim-enzim tertentu. Minyak atsiri diketahui memiliki sifat insektisida terhadap hama gudang Callosobruchusmaculatus dan chantoschelides obtectus, ulat daun bawang, Spodoptera exigua (Irfan, 2005), penggorok daun bawang (Suryaningsih, 2006), nyamuk Aedes 
aegypti (Wardani, 2009), dan rayap tanah (Latumahina, 2010). Hasil penelitian Ahmad (2015) pada pengujian di laboratorium dengan pemanfaatan ekstrak tembakau pada hama ulat grayak dengan konsentrasi $350 \quad \mathrm{ml}$ menyebabkan mortalitas hama ulat grayak sebesar 95\%. Berdasarkan informasi tersebut penelitian ini bertujuan untuk mendapatkan jenis pada pengaruh beberapa jenis pestisida nabati terhadap hama ulat grayak Spodoptera litura F. pada tanaman sawi (Brassicia juncea $\mathrm{L}$ ) di lapangan.

\section{METODE PENELITIAN}

Penelitian ini dilaksanakan di kebun milik petani di Kelurahan Rewa Rangga Selatan Kecamtan Ende Timur Kabupaten Ende Waktu Percobaan mulai bulan Oktober sampai November \pm 2 bulan 2015. Bahan-bahan yang digunakan dalam penelitian ini adalah daun tembakau segar, daun cengkeh segar, daun serai segar, biji nimba dan buah cabai, deterjen, air dan tanaman sawi varietas tosakan. Alat-alat yang digunakan dalam penelitian ini adalah ember, saringan, alat semprot, timbangan, dan alat tulis. Penelitian ini menggunakan Rancangan Acak Kelompok (RAK) yang terdiri atas 5 perlakuan konsentrasi ekstrak daun tembakau yaitu: $E_{1}$ : Ekstrak daun tembakau, $E_{2}$ : Ekstrak daun cengkeh, $E_{3}$ : Ekstrak daun serai, E4: Ekstrak biji nimba dan $E_{5}$ : Ekstrak buah cabai. Setiap perlakuan diulang sebanyak 4 kali sehingga terdapat 20 satuan percobaan. Variabel Pengamatan 1) Mortalitas hama ulat grayak, 2) Intensitas serangan, 3) Berat segar sawi $\tan ^{-1}$ dan berat segar sawi ha ${ }^{-1}$. Data hasil pengamatan dianalisis dengan menggunakan analisis sidik ragam sesuai rancangan yang digunakan. Apabila perlakuan menunjukkan pengaruh yang nyata atau pengaruh yang sangat nyata terhadap variabel yang diamati, maka dilanjutkan dengan uji nilai beda rata-rata menggunakan uji BNT 5\% (Gomez dan Gomez, 2007).

\section{PEMBAHASAN}

Hasil analisis sidik ragam menunjukkan bahwa ekstrak tanaman tembakau, cengkeh, serai, nimba dan buah cabai merah berpengaruh nyata terhadap mortalitas hama Spodoptera litura F. Pada variable pengamatan mortalitas hama, (Tabel 1). Hasil penelitian menunjukkan bahwa ekstrak daun tembakau (E1) menyebakan mortalitas ulat grayak $S$. litura F. pada tanman sawi sebesar $76,25 \%$, ekstrak daun cengkeh sebesar $66,75 \%$, ekstrak dau serai sebesar $63,5 \%$, ekstrak biiji nimba sebesar $61,5 \%$ dan ekstrak buah cabai sebesar 64\%. Mortalitas ulat grayak disebabkan semua jenis pestisida mengandung senyawa bahan aktif bersifat sebagai racun perut, racun kontak, racun syaraf dan repellen bagi hama.

Tembakau merupakan produksi pertanian yang diproses dari daun tanaman dari genus Nicotiana. Kandungan nikotin yang ada dalam tembakau merupakan golongan alkaloid yang terdapat dalam familii solanaceae. Kadar nikotin berkisar antara 0,6-3,0\% dari berat kering tembakau, dimana proses biosintesisnya terjadi diakar dan terakumulasi pada daun tembakau yang 
berfungsi sebagai bahan kimia anti hebivora dan adanya kandungan neurotoxin yang sangat sensitive bagi serangga menyebabkan nikotin dapat digunakan sebagai pestisida menjadi racun syaraf yang potesial (Abdullah dan Ahmad Soedarmanto, 2003).

Kandungan daun cengkeh memiliki kandungan minyak atsiri yang cukup tinggi. Setiap bagian pohon mengandung minyak, mulai dari bunga, daun, gagang hingga akar. Kandungan minyak cengkeh pada tanaman cengkeh bervariasi jumlahnya, namun yang tertinggi terdapat pada bagian bunga yaitu sekitar 14-21\%, sedangkan pada gagang cengkeh yaitu sekitar 5 minyak cengkeh adalah minyak yang berasal dari tanaman cengkeh. Minyak cengkeh merupakan bahan aktif sebagai herbisida dimana efektif dalam membasmi berbagai jenis hama tanaman. Selain itu, minyak cengkeh dapat digunakan untuk obat nyamuk. Minyak cengkeh dianggap sangat aman dalam jumlah kecil $(<1500$ ppm) sebagai makanan tambahan. Namun, minyak cengkeh dapat berbahaya, termasuk menyebabkan distress sindrom pernafasan akut dan system saraf pusat depresi (Anonim, 2009).

Tabel 4.1 Pengaruh jenis pestisida nabati terhada mortalitas hama ulat grayak Spodoptera Litura F pada tanaman sawi dilapang.

\begin{tabular}{cc}
\hline Perlakuan & Mortalitas (\%) \\
\hline E1 & $76,25 \mathrm{a}$ \\
E2 & $66,75 \mathrm{~b}$ \\
E3 & $63,5 \mathrm{c}$ \\
E4 & $61,5 \mathrm{~d}$ \\
E5 & $64 \mathrm{e}$ \\
\hline BNT & 1,37 \\
\hline
\end{tabular}

Keterangan : Angka-angka yang diikuti oleh huruf yang sama pada kolomyang sama berarti tidak berbeda nyata pada uji BNT taraf 5\%.Data di transfomasikan dengan arcsin.

Tanaman serai (Cymbopogon nardus L) dapat dimanfaatkan sebagai pengusir serangga karena mengandung zat-zat seperti saponin dan tannin senyawa saponin sebagai racun kontak dan anti mikrobir, bakteri (jamu,bakteri dan virus), bersifat fisiologi dan dapat menghambat terbentuknya komponen sel seperti sintesis dinding sel, membrane sitoplasma, sintesis protein dan sintesis asam nukleat (Soebandrio, 1995 dalam Ariati 2008). Senyawa tannin sebagai penolak serangga. Kandungan nintronella dan grenyl, karena di dalam kandungan ini terdapat dua senyawa yaitu saponin dan tannin, senyawa ini bekerja sebgai racun kontak dan repellan.

Biji mimba banyak terkandung minyak dan bahan aktif pestisida sehingga banyak dimanfaatkan untuk pengendalian hama. Salah satu komponen kimia yang terkandung dalam biji mimba yaitu zat azadirachtin. Senyawa ini merupakan racun dan mempunyai daya bunuh terhadap 
serangga hama tanaman. Senyawa lain yang berfungsi sebagai bahan bioaktif pestisida adalah mimbin, thionemon, meliantriol dan salanin yang merupakan senyawa kimia dari kelompok terpena. Ekstrak bioaktif tetranotiterpinoid azadirachtin efektif terhadap lebih dari 200 spesies serangga hama. Ekstrak biji mimba sebagai insektisida hayati mempunyai daya kerja yang efektif, ekonomis dan aman. Mimba bersifat repellent yaitu menolak kehadiran serangga terutama karena baunya yang menyengat (Subyakto, 2009).

Cabai merah memiliki kandungan kimia yang terdiri dari saponin, flavonoid, polifenol, alkaloid dan minyak atsiri (Leung dan Foster, 2006). Cabai merah memiliki manfaat sebagai racun kontak dan repellan. Minyak atsiri cabai merah terdiri dari sitral, sitronelal, geraniol, mirsena, nerol, farsenol, metilheptenon, dipentena, eugenol metil eter, kadinen, kadinol dan limonene (Wijayakusumah, 2000). Senyawa geraniol dan sitronellal dilaporkan dapat berfungsi sebagai fungisida nabati (Miftakhurohmah, 2008). Eugenol yang terkandung dalam cabai merah mempunyai pengaruh dalam menghambat pertumbuhan dan perkembangan jamur patogen (Pitojo, 2006). Hasil ini menunjukkan bahwa hipotesis pertama terbukti.

Hal ini disebabkan oleh jenis kandungan bahan aktif yang dapat menghambat perkembangan sehingga menyebabkan mortalitas Spodoptera Litura F. lebih banyak (Yuphy, 2011). Daun tembakau sebagai repellan atau penolak serangga. Daun tembakau mengandung nikotin dan alkaloid.
Senyawa yang terkandung pada alkaloid nikotin, nikotin sulfat dan senyawa nikotin lainnya. Senyawa ini bekerja sebagai racun kontak, racun perut dan fumigan. Daun tembakau kering mengandung 2-8\% nikotin. Nikotin merupakan racun syaraf yang bereaksi cepat. Nikotin berperan sebagai racun kontak bagi serangga seperti: ulat perusak daun, aphids, triphs, dan pengendali jamur (fungisida). berdasarkan hasil tersebut maka hipotesis pertama terbukti karena tingkat mortalitas hama berbeda.

Daun cengkeh (Zinzigum aromatium) mengandung minyak atsiri menyebabkan distress sindrom pernafasan akut dan system saraf. Dari hasil tesebut maka hipotes kedua tidak tebukti. Tanaman serai (Cymbopogon nardus L) dapat dimanfaatkan sebagai pengusir serangga karena mengandung zat-zat seperti saponin dan tannin senyawa saponin sebagai racun kontak dan antimikroba, bakteri (jamu, bakteri dan virus), bersifat antioksida, bahan yang bersifat sebagai anti bakteri dapat menganggu proses fisiologi dan menghambat terbentuknya komponen sel seperti sintesis dinding sel, membrane sitoplasma, sintesis protein dan sintesis asam nukleat (Soebandrio, 1995 dalam Ariati, 2008).

Biji nimba mengandung azadirachtinmeliantriol, salanin, dan nimbin, yang merupakan hasil metabolit sekunder dari tanaman mimba. Mimba bersifat repellent yaitu menolak kehadiran serangga terutama karena baunya yang menyengat (Sukrasno, 2003). 
Sedangkan cabai merah memiliki kandungan kimia yang terdiri dari saponin, flavonoid, polifenol, alkaloid dan minyak atsiri (Leung dan Foster, 2006). Cabai merah memiliki manfaat sebagai racun kontak dan repellan. Minyak atsiri cabai merah terdiri dari sitral, sitronelal, geraniol, mirsena, nerol, farsenol, metilheptenon, dipentena, eugenol metil eter, kadinen, kadinol dan limonene (Wijayakusumah, 2000). Senyawa geraniol dan sitronellal dilaporkan dapat berfungsi sebagai fungisida nabati (Miftakhurohmah, 2008). Eugenol yang terkandung dalam cabai merah mempunyai pengaruh dalam menghambat pertumbuhan dan perkembangan jamur patogen (Pitojo, 2006).

Perlakuan ekstrak daun tembakau (E1) menyebabkan mortalitas ulat grayak paling tinggi sebesar 76,25 dibandingkan jenis pestisida yang lain. Hal ini disebabkan karena esktrak daun tembakau mengandung senyawa nikotin yang di dalamnya terkandung senyawa alkaloid dan saponin yang bekerja sebagai racun konyak, racun perut dan racun saraf pada serangga. Senyawa alkaloid banyak terkandung dalam akar, biji, kayu, maupun dari daun tumbuhan. Peran alkaloid bagi tumbuhan sebagai zat racun yang melingdungi tumbuhan dari serangga. Alkaloid lebih cepat larut, sehingga bahan aktif yang masuk ke dalam tubuh serangga melalui kutikula dan trachea dapat langsung merusak fungsi sel serangga sehingga menyebabkan mortalitas (Tobing, 1989).

Senyawa saponin yang memiliki aktifitas racun kontak langsung bekerja ketika terjadi kontak antara serangga dan masuk melalui kuitikula atau trachea atau langsung mengenai mulut serangga dan menembus integument. Kneblock (1989) menyatakan bahwa senyawa saponin bersifat sangat racun dan antimikroba (jamur, bakteri, virus), bahan aktif yang memiliki sifat daya larut tinggi dalam air akan mudah menembus lapisan fosfolipid membrane sel sehingga lebih cepat menggangu fungi fisiologis yang pada akhirnya sel akan mengalami kematian (Soebandrio, 1995 dalam Ariati, 2008).

Hasil ini menunjukkan bahwa hipotesis kedua tidak terbukti. Hal ini kemungkinan disebabkan ekstrak daun cengkeh yang mengandung minyak atsiri tersebut memiliki sifat sukar larut dalam air sehingga menyebabkan mortalitas ulat menjadi rendah. Hasil analisis sidik ragam menunjukan bahwa jenis pestisida nabati berpengaruh nyata terhadap intensitas serangan hama Spodoptera Litura F. pada tanaman sawi di lapang (Tabel 2).

Hasil penelitian menunjukkan bahwa ekstrak daun tembakau (E1) menyebabkan intensitas serangan ulat grayak $S$. Litura $F$. pada tanaman sawi sebesar $25 \%$, ekstrak daun cengkeh sebesar $41 \%$, eksrtak daun serai sebesar $39,75 \%$, eksrtak biji nimba sebesar $39,50 \%$ dan eksrtak buah cabai sebesar $40,25 \%$.

Hasil penelitian menunjukkan bahwa ekstrak daun tembakau (E1) menyebabkan intensitas serangan ulat grayak S. Litura $F$. pada tanaman sawi sebesar $25 \%$, ekstrak daun cengkeh sebesar $41 \%$, eksrtak daun serai sebesar $39,75 \%$, eksrtak biji nimba sebesar 
$39,50 \%$ dan eksrtak buah cabai sebesar $40,25 \%$.

Perlakuan eksrtak daun tembakau (E1) menyebakan intensitas serangan ulat grayak paling rendah sebesar $25 \%$ dibandingkan jenis pestisida yang lain. Hal ini disebabkan karena ekstrak daun tembakau mengandung senyawa nikotin yang di dalamnya terkandung senyawa alkaloid dan saponin yang bekerja sebagai racun kontak, racun perut dan racun saraf pada serangga. Senyawa alkaloid banyak terkandung dalam akar, biji, kayu maupun daun dari tumbuhan. Peran alkaloid bagi tumbuhan sebagai zat racun yang melindungi tumbuhan dari serangga. Alkaloid lebih cepat larut, sehingga bahan aktif yang massuk ke dalam tubuh serangga melalui kutikula dan trachea dapat langsung merusak fungsi sel serangga sehingga menyebabkan mortalitas (Tobing, 1989). Senyawa saponin yang memiliki aktifitas racun kontak langsung bekerja ketika terjadi kontak antara serangga dan masuk melalui kuitikula atau trachea atau langsung mengenai mulut serangga dan menembus integument. Kneblock (1989) menyatakan bahwa senyawa saponin bersifat sangat racun dan antimikroba (jamur, bakteri, virus), bahan aktif yang memiliki sifat daya larut tinggi dalam air akan mudah menembus lapisan fosfolipid membrane sel sehingga lebih cepat menggangu fungi fisiologis yang pada akhirnya sel akan mengalami kematian (Soebandrio, 1995 dalam Ariati, 2008). Mortalitas hama yang disebabkan oleh senyawa alkaloid dan saponin dalam ekstark daun tembakau menyebabkan penurunan intensitas serangan ulat grayak pada tanaman sawi.

Hasil ini menunjukkan bahwa hipotesis kedua tidak terbukti. Hal ini kemungkinan disebabkan ekstrak daun cengkeh yang mengandung minyak atsiri tersebut memiliki sifat sukar larut dalam air sehingga menyebabkan mortalitas ulat menjadi rendah dan intensitas serangan sebesar $41 \%$.

Tabel 2 Pengaruh Jenis Pestisida Nabati Terhadap Intensitas Serangan Hama Ulat Grayak Spodoptera Litura F. Pada Tanaman Sawi di Lapang

\begin{tabular}{cc}
\hline Perlakuan & Intensitas serangan (\%) \\
\hline E1 & $25,00 \mathrm{a}$ \\
E2 & $41.00 \mathrm{~b}$ \\
E3 & $39.75 \mathrm{c}$ \\
E4 & $39.50 \mathrm{~d}$ \\
E5 & $40.25 \mathrm{e}$ \\
BNT & 5,58 \\
\hline
\end{tabular}

Keterangan: Angka-angka yang diikuti oleh huruf yang sama pada kolomyangsama berarti tidak berbeda nyata pada uji BNT taraf 5\%. Data ditransformasikan dengan arcsin. 


\section{KESIMPULAN}

Efektivitas estrak daun tembakau berpengaruh nyata pada penurunan intensitas kerusakan hama pada tanaman sawi. E1 $(100 \mathrm{ml})$ sebesar 25,00\%; E2 (100 ml) sebesar 41.00\%; E3 (100 ml) sebesar 39.75\%; E4 (100 $\mathrm{ml})$ sebesar $39.50 \%$ dan E5 (100 ml) sebesar $39.50 \%$ dan berpengaruh nyata pada tingkat mortalitas hama E1 (100 $\mathrm{ml})$ sebesar 76,25\%; $\mathrm{E} 2(100 \mathrm{ml})$ sebesar 66,75\%; E3 (100 ml ) sebesar 63,5\%; E4 (100 ml) sebesar 61, 5\% dan E5 (100 ml) sebesar 25,00\%, serta berpengaruh nyata pada berat segar tanaman sawi E1 (100 ml) 25,00 gr; E2 (100 ml) $102.55 \mathrm{gr}$; E3 (100 ml) 100.5 gr; E4 (100 ml ) 99.85 gr dan E5 (100 ml) 103.52 gr, sedangkan berat segar perhektar E1 $(100 \mathrm{ml}) 28.21$ ton; E2 (100 ml) 25.64 ton; E3 (100 ml) 25,13 ton; E4 (100 ml) 24.96 ton; E5 (100 ml) 25.46 ton.

Jenis pestisida yang paling efektif terhadap variable pengamatan intensitas kerusakan, mortalitas, berat segar pertanaman dan berat segar perhektar terdapat pada perlakuan konsentrasi ekstrak daun tembakau (E1).

\section{DAFTAR PUSTAKA}

Abdullah, Ahmad Soedarmanto. 2003. Budidaya Tembakau dan pemanfaatannya. Jakarta : CV Yasaguna.

Anonim $^{1}$, 2009. http://niellastory.wordpress.com/p raktikum. Diakses 15 Agustus 2011

Ariati, Ni Komang. 2008. Aktivitas bakterisida ekstrak cem cem
Spondias pinnata terhadap bakteri Erwinia chyrysanthemi penyebab busuk lunak lidah buaya. Tesis. Universitas Udayana, Denpasar.

BPS dan Direkorat Jendral Hortikultura. 2013. Statistik Pertanian (Agricultura

Statisties).2008.DepertemenPerta nainRepublikIndonesia.Jakarta. $(\underline{h t}$ tp://www.bps.go.id/booklet/Boklet februari_2014 pdf). Disidir 21 februari 2014.

BPS Kabupaten Ende. 2014. Ende Dalam Angka. Badan Pusat Statistik Kabupaten Ende.

BPS NTT. 2014. NTT Dalam Angka. Badan Pusat Statistik Propinsi NTT

Dbph direktorat jenderal bina produksi hortikultura. 2007. Perkembangan Luas Panen Sayuran. 1996-2005. http://www.deptan.go.id.(diakses tanggal 01 Januari 2014).

Gomez, K.A., Gomes, A.A 2007. Prosedur Statistik Untuk Penelitian PertanianPertanian.edisi ke 2 jakarta :universitas indonesia.

Hartati, Ahmad. 2015.Uji Efektivitas Ekstrak Daun Tembakau Terhadap Ulat Grayak, Uniflor:Skripsi. Ende.

Haryanto, E. 2001. Budidaya Sawi dan Selada, Penebar Swadaya, Jakarta.

Irfan, M. 2005. Pengaruh Ekstrak Sereh Wangi (Androphogon nardus 
L.)terhadap Mortalitas Larva Spodoptera exigua Hubner (Lepidoptera : Noctuidae). Skripsi. Jurusan Hama dan Penyakit FakultasPertanian Universitas Tadulako.Palu. Hal. 27. J. Econ. Entomol. 99 (1): 176181.

Leung. A. Y., Foster S. 2006. Encyclopedia of common natural ingredients used in food, drugs and cosmetic. Ed ke-2. New York: John Wiley \& Sons.

Magdalena. 2008. Keragaman Ukuran dan Warna Spodoptera litura F. pada Tanaman Sawi (Brassica juncea L.) diBerbagai Ketinggian Tempat. Skripsi. Bogor (ID): Fakultas Pertanian,Institut Pertanian Bogor

Mardiningsih, Tri. L dan Barriyah Barimbing. 1995. Biologi S.litura F. Pada Tanaman Kemiri. Dalam Pro siding Seminar Nasional Tantang an Entomologi pada Abad XXI. P erhimbunan Entomologi Indonesi

a. Balai TanamanRempah danOba t. Bogor. 96-102 hal.

Marwoto dan Suharsono. 1991. Penggunaan Produk Alam Dalam Pengendalian Hama Terpadu. PAU Ilmu Hayati ITB.

Maya Rumpumbo. 2010. Pengujian ekstrak biji mimba terhadap hama plutella xylostella pada tanaman kubis.Skripsi. Fakultas pertanian dan teknologi pertanian universitas papua.
Miftakhurohmah. 2008. Potensi Cabai Merah Sebagai Pestisida Nabati. Dalam Warta Penelitian dan Pengembangan Tanaman Industri, Vol. 14 Nomo3. Desember 2008. Jakarta. Badan Penelitian dan Pengembangan Pertanian. Pusat Penelitian dan Pengembangan Perkebunan. 33 hal.

Natawigena. 1989. Pestisida Dan Kegunaannya. Bandung: CV Armico.

Oleszek WA. 2000. Saponins. Di dalam. Naidu AS, Editor. Natural Food Antimicrobial System. New York: CRC Press.

Pitojo, S. 2006. Kandungan Kimia Cabai Merah. Trubus Agriwidia Ungaran. Jakarta. 48 hal.

Pracaya. 2005. Membuat dan Memanfaatkan Pestisida Ramah Lingkungan. Agro Media Pustaka. Jakarta.

Rukmana. 2007. Bertanam Sawi. Kanisius. Yogyakarta. 48 hal.

Samsudin2008. Kerusakan dan populasi ulat grayak Spodoptera litura.pada berbagai tanaman Seminar Balai Penelitian Tanaman Pangan Bogor Tahun 1986.

Subyakto, 2009. Ekstrak biji nimba sebagai pestisida nabati : Penebar Swadaya, Jakarta

Sudarmo.1992.Preferensi Spodoptera lit ura F. Terhadap BeberapaPakan. J urnal Pertanian dan Biologi- 
Universitas Medan Area. 1(1): 2930.

Tengkano dan Soehardjan (1985), Pengendalian Hama Terpadu Dan Implementasinya. Indonesia.

Warsi Rahmat Atmadja 2010 pemanfaatan lima jenis insektisida nabati untuk mengendalikan ulat grayak (Spodoptera litura F)pada tanaman cabe.

Wijayakusuma. 2000. Tumbuhan Berkhasiat Obat Indonesia.Jakarta: Milenia Popular.

Haidar, M. H., L. Nurdiana., dan R. Amalia. 2012. Pemanfaatan
Ekstrak Nikotin LimbahPuntungRokokhttp://repos itory.upnyk.ac.id/6153/1/sri_suhe nry_exergi_november_2015.pd

Haidar, M. H., L. Nurdiana., dan R. Amalia. 2012. Pemanfaatan Ekstrak Nikotin LimbahPuntungRokokhttp://repos itory.upnyk.ac.id/6153/1/sri_suhe nry_exergi_november_2015.pd

Doli, Oppung. 2013. Isolasi dan Ekstraksi Isolasi dan Ekstraksihttp://www.kompasiana. com/painan/tembakau-sejarahkandungan-dan- kegunaannya. Diakses 15 Noveember 2015. 